\title{
Mergers and Acquisitions (M\&A) as Modern Ways of Investments
}

\author{
Inese Mavlutova $^{1}$, Gregory Olevsky ${ }^{2}$
}

\begin{abstract}
:
The decrease in business activity and the fall in the production volume in the sectors of economy relying on long-term crediting is characteristic feature of the modern recessions.

The pessimistic expectations of entrepreneurs concerning product demand leads to falling direct investment into business despite unlimited investment opportunities due to the developed capital markets nowadays.

As a result it has created the opportunity for the development of the acquisition of enterprises. Potential investors are different and their investment motivation is different, but the goal is the same - to increase the value of the business and its efficiency as a result of mergers and acquisitions. However, purchasable enterprises are exposed to several financial risk factors.
\end{abstract}

Key Words: Recession, financial investors, mergers, acquisitions, M\&A cycles.

\footnotetext{
${ }^{1}$ BA School of Business and Finance, Kr. Valdemara str.161, Riga, Latvia, E-mail: inese.mavlutova@ba.lv

${ }^{2}$ University of Latvia, Professor, Raina bulv. 19, Riga, Latvia, E-mail: grigol@lanet.lv
} 


\section{Introduction}

The economic development in one country depends on the economic situation in other countries in the modern business world. Therefore the crisis in the banking sector and real estate market in the USA, which is recognized to be the leading country in the global economy, was the accelerator of recession in many countries. Consequently, according to the opinion of the experts of the international rating agency "Fitch Ratings" such largest industrialized countries in the world as USA, Great Britain, the countries of the euro zone and Japan in 2009 will experience the most substantial GDP downturn since World War II.

The authors of the article suggest that the complicated situation as regards the availability of crediting combined with the decrease in demand and the volume of corporate investments leads to the uncharacteristic simultaneous recession in the EU countries. The decrease in business activity and the fall in the production volume in the sectors of economy relying on long-term crediting is characteristic feature of the modern recessions. The pessimistic expectations of entrepreneurs concerning product demand leads to falling direct investment into business despite unlimited investment opportunities due to the developed capital markets nowadays.

The objects of research, the results of which are presented in the article are the merging and acquisition of enterprises, known as M\&A in business environment, as one of the most attractive ways of investment nowadays. The goal is to prove that M\&A under the conditions of recession compete quite successfully with other types of investment in attracting free funds. The paper attempts to present the analysis of investment process nowadays.

The main methods of research were the analysis of statistic data, quantitative and qualitative comparison of M\&A process in Latvia and other EU countries, based on experts' opinion and on personal observation.

\section{Discussion}

Everything is in a close correlation in the business world. The economic development in one country depends on the economic situation in other countries. The experts believe that the complicated situation as regards the availability of crediting combined with the decrease in demand and the volume of corporate investments leads to the uncharacteristic simultaneous recession in the developed countries.

The "compression" of production results in reduced demand in labor market which leads to the growth of unemployment rate and decrease of real wages. During recession appears the tendency of fast decrease in the prices for energy and raw materials. The pessimistic expectations of entrepreneurs concerning product demand leads to falling direct investment into business. The merging and acquisition of 
enterprises, known as M\&A in business environment, is one of the most attractive ways of investment which under the conditions of recession competes quite successfully with other types of investment in attracting free funds.

As a result of globalization and the changing economic environment the life cycle of enterprises has become shorter, business has become dynamic and it has created the opportunity for the development of the acquisition of enterprises. Potential investors (buyers) are different and their investment motivation is different, but the goal is the same - to increase the value of the business and its efficiency as a result of the acquisition.

Therefore these transactions are vital both for the encouraging of entrepreneurship and the development of national economy. As any investors they are interested not only in the processes at the microeconomic level, but also the investment environment on the whole - macroeconomic indicators and favorable conditions for the business development.

There is not only high risk, but also the necessity to think strategically and to act flexibly during recession. The acquisition of the enterprise from the point of view of the investor requires careful analyses of the processes looking for the optimal solution. The business success of the investor depends on it. The acquisition of the enterprise involves high risk and uncertainty, but also high return in case of success.

Financial markets have expanded rapidly during last years thus new financing alternatives for acquisition of enterprises have developed, for example, second lien debt. It is characterized as combination between bank financing and mezzanine financing with regard to loan term and conditions.

Concerning security second lien debt is subordinate to bank loan - if the guaranty becomes required, gained resources initially are shifted to extinguish the bank debt completely and only remaining amount is spent to repay the second lien debt .

Admittedly, to finance acquisition of enterprises there is a great amount of different secondary financial instruments in market that can be used. Wide range of financial instruments allows flexible cash flow of the purchasable company, therefore it is possible to customize repayment schedule in accordance with resources of acquired company.

According to Figure 1, European LBO's (acquisition of enterprises, utilizing significant proportion of borrowed capital) structure of transactions is following: bank loans are dominant (50\%), followed by equity (20\%) as well as owner loans $(12 \%)$, which is possible together with equity. 
Figure 1: Financial sources of European LBO (leverage buyout) operations in $2006(\%)$

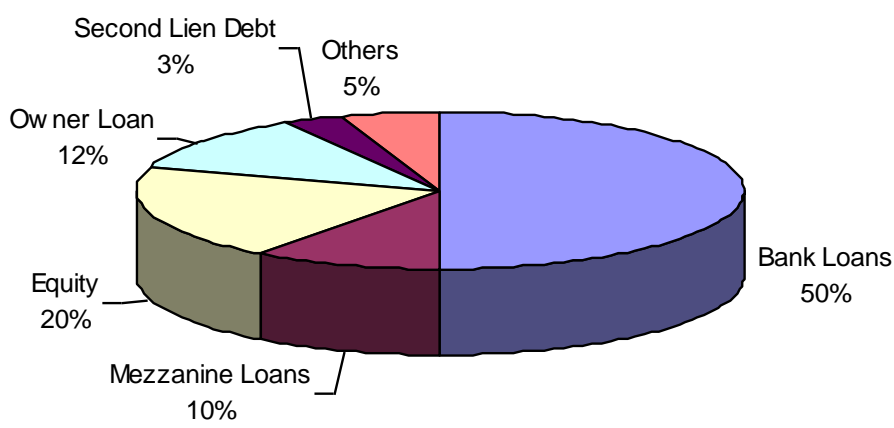

Transaction's financial leverage and level of complexity depends largely on the scope of the operation - wide range of financial sources is more typical for largerscale deals. Financing smaller LBO transactions is mostly still delegated to only one creditor - bank. In case the bank is not willing to take all the credit-risk, borrower may give a permission to other banks to come to terms of syndicate credit, thereby loan is provided by several banks and the credit-risk is divided accordingly.

Eligible leverage depends on a range of factors - total growth of national economy, industry represented by purchased enterprise, perspective, seasonality, expanding potential, market fluctuations, stability of company's economic activities and other significant factors. It is relevant to mention that each project of purchasing an enterprise is evaluated accurately by associates, i.e. investors.

Assessment of purchasable company's credit standing in the future is the key factor potential investors are considering. If bank makes a decision to participate in financing the operation, specific conditions or covenants are included in credit agreement as an instrument to determine difficulties in enterprise timely, since repayment of LBO credit is based solely on purchasable enterprise's future cash flow.

Thus freedom of action of new owners is restricted by covenants in relation of such transactions as selling assets or paying dividends, and operations that are not related to ensuring economic activities have to be coordinated by investors. Moreover, banks have postulated to keep some previously defined financial indicators at certain level. Inability to meet the specific conditions may lead to bank's request for repaying the loan immediately.

Utilizing borrowed capital for financing acquisitions of enterprises has following advantages: 
- "Debt discipline". Due to liabilities assumed by company, it stimulates management to focus on arranging economic activities, which might have been canceled or delayed. Thereby increase of liabilities is not only financial strategy, but also an instrument to accelerate changes in the level of management.

- It is possible for investors to obtain an enterprise for undersized capital necessary, for as the commitment proportion grows, equity proportion decreases. Saved funds can be invested for financing other operations.

- Income chargeable with corporate income tax can be reduced by the amount of the interest costs.

- Enterprise can boost its value by increasing the burden of liabilities up to level with the highest profitability of equity.

- Equity often includes managers together with investors, thus inspiring (or even requiring) higher management to invest a remarkable amount of their personal funds in to the transaction. Thereby equal motivation is guaranteed for both investors and management.

However, purchasable enterprise is put in jeopardize by several risk factors, since taking part in financial commitments. Increase of financial risk is the head. Unpredictable events such as recession, litigation or changes in legal environment can lead to inability to cover fixed interest, non-fulfillment of technical obligations (by breaking covenants), or even complete liquidation of enterprise - in this case shareholders lose all invested capital.

Value that financial buyer expects from the LBO transaction is related to increase of sales and profitability, as well as appropriate management of working capital and capital investment. Success of LBO operation can be threatened both by weak management of purchasable enterprise and differences in motivation of managers and owners. Furthermore, if increase of interest scales up fixed costs, capability of enterprise to endure through business and economic recession decreases.

It has been proved in science long ago that the mergers and acquisitions are cyclical. Five full cycles of the enterprise mergers and acquisitions have been described in literature: the beginning of the $20^{\text {th }}$ century, in $1920 \mathrm{~s}, 1960 \mathrm{~s}, 1980 \mathrm{~s}$ and $1990 \mathrm{~s}$. The last cycle in 1990s was special as regards the volume and geographical boundaries. First the European (except British) entrepreneurs actively participated in acquisitions and mergers as it was done earlier by their USA and British colleagues. The acquisition and merger market in Europe reached the size of the USA market which had already been the most developed. Since the middle of 2003 the merger and acquisition market has experienced growth after the sudden gap in 2001. It seems that the global recession has already allowed experiencing the end of the sixth cycle of the enterprise acquisitions.

Though the end of the sixth cycle has not been mentioned in literature yet, still it is possible that 2007 could be marked as a period which could refer to the end of the 
current cycle of enterprise mergers and acquisitions. As the main precondition of such an opinion serves the collapse of the financial market, which started in 2007 in the USA and in 2008 reached also Europe.

The following tendencies are expected in the world enterprise merger and acquisition market in the nearest future:

- The conditions of financing will become stricter - the recent events in the capital markets, future uncertainty will make the creditors (especially banks) return to stricter covenants. Besides the cost of capital will remain high.

- Financial investors will adapt to the new environment that will make them give up aggressive financing structures. The total loan capital proportion in financing transactions will shrink. As a result the financial investors will be forced to invest more their own funds. In some recent deals financial investors' contribution in their financing was nearly $50 \%$.

- The number of large deals with a purchasing price above 300 million dollars continues to decrease. Financial investors will turn to smaller enterprises that will allow diversifying the investors' portfolio thus spreading the risk.

- The common opinion is that the price of enterprises should continue to fall because less financing is available and very often it is impossible to finance the deal, but if it takes place, it takes more time.

- The global economy does not grow as quickly as it has been recently, even a long phase of recession is possible therefore the financial investors will have to prove their professionalism in increasing the value of the enterprise and improving the cash flow to maintain high profitability from investments because up to now the clue to the investors' success was the favorable economic environment and the fact that the average enterprise price indicators increased what allowed after some time to conclude the deal with profit even without improving financial indicators. Financial investors more often will follow the investment strategy "buy and build" that allows to achieve much faster growth of the enterprise value through the merger of several enterprises:

- Strategic investors will become more competitive because they will be able to compete with financial investors as regards the price because the latter will face difficulties in attracting capital.

- Enterprises with large burden of liabilities which they are not able to settle or so called distress enterprises will become potential investment objects if the investors see the possibility to restructure the enterprise. Some of the venture capitalists have already founded special funds which will specialize in acquisition of the enterprises which are in financial difficulties.

- The possibility of more serious governmental regulation of the deals concerning enterprise acquisition cannot be excluded. For instance, after the tremor in financial markets in autumn 2008, European Commission has announced the decision that suggests implementing a stricter supervision of venture capital funds because according to the present procedure their activities are not sufficiently regulated. 
The biggest problem in the Baltic states and therefore also in Latvia is the fact that government institutions do not monitor constantly the enterprise merger and acquisition deals. Therefore there is no statistical data about the number of deals and their value. There are merger and acquisition deals in Latvian market, but they are basically related to selling stocks to foreign investors by local entrepreneurs and not buying them from foreign enterprises as well as there are few acquisition deals in territory of Latvia.

There are more large size concerns in Lithuania; therefore they are more active in acquisition of enterprises and attracting foreign capital for development. Estonian enterprises are rather active in acquisition deals and attracting of capital, they have more developed capital market. Foreign investors seldom consider Latvia as a separate region for investment Mostly they consider the whole Baltic market or even the Baltic Sea region. Such a division of regions shows that often the acquisition of an enterprise in Latvia is only a part of the implementation of a larger plan.

According to the research of Deloitte Latvia which evaluated the attraction of the Baltic States for financial investors or venture capital funds, it was concluded that the most favorable investment environment is in Latvia in comparison to other Baltic States. The results of the research show that taxation and legislation in Latvia is very favorable for the deals related to the acquisition of enterprises which are financed by crediting LBO or leveraged buyout. One of the most attractive factors for investing in Latvia is the low corporate income tax rate, which is one of the lowest in Europe.

The forecasts are that in 3-5 years financial investors (Private Equity funds) who have invested successfully and developed enterprises in Latvia are going to sell their activities. After that a new wave will come and investors are going to attract major strategic investors from Europe and Scandinavia. Also there are investors practicing "buy and build' strategy - they purchase an enterprise in Latvia and then observe and buy companies in other Baltic states in order to merge then into one enterprise.

There are micro-enterprises according world standards in Latvia, thus value of transactions is insignificant compared to global scales. According to data of corporate finance consultant company Behrens Corporate Finances, there has been 31 acquisition operations in 2008 made by foreign investors.

Total amount of acquisition transactions in Latvia is unexplored, but it could similar, assuming that domestic investors are relatively inactive. As summarized in Table 1, information about investors' country of origin reflects that the most active buyers of enterprises are Estonians by acquiring 8 companies in 2008 .

In the following table all types of investors are summed up, without marking out strategic and financial investments or how many operations are involving foreign risk capital funds. 
Table 1: Number of acquired enterprises in Latvia by investor's country of origin

\begin{tabular}{|l|l|l|l|}
\hline country & 2008 & 2007 & 2006 \\
\hline USA & 0 & 2 & 0 \\
\hline CEE* & 2 & 0 & 0 \\
\hline Denmark & 1 & 0 & 2 \\
\hline France & 0 & 1 & 0 \\
\hline Germany & 1 & 0 & 1 \\
\hline Estonia & 8 & 4 & 1 \\
\hline Ireland & 1 & 0 & 1 \\
\hline Iceland & 5 & 6 & 0 \\
\hline Cyprus & 1 & 0 & 1 \\
\hline Russia & 2 & 1 & 1 \\
\hline Great Britain & 1 & 0 & 1 \\
\hline Lithuania & 2 & 0 & 2 \\
\hline Luxemburg & 0 & 1 & 0 \\
\hline Netherlands & 1 & 1 & 0 \\
\hline Norway & 0 & 2 & 0 \\
\hline Finland & 1 & 2 & 4 \\
\hline Switzerland & 0 & 0 & 1 \\
\hline Turkey & 1 & 0 & 0 \\
\hline Ukraine & 1 & 0 & 0 \\
\hline Sweden & 3 & 1 & 3 \\
\hline Total: & 31 & 21 & 18 \\
\hline$*$ CAE - Central and East-Europe \\
\hline
\end{tabular}

Table shows that there is the largest number of transactions in 2008; it has increased by $48 \%$ compared to 2007 and by $72 \%$ compared to 2006 . Remarkable take-off in increasing amount of deals was Latvia's alignment to European Union in 2004, which resulted in increase of confidence about Latvia's macro- and microeconomic environment from strategic and financial investors.

Nordic countries maintain the top position in purchasing enterprises. Investors from Iceland have been particularly active in last years, however investors from other countries have paid special attention to Latvian enterprises in last 2 years.

In due to raise investment funds the most attractive industries are financing and insurance area, as well as food and alcohol production and merchandising. In 2008 there have been 3 deals closed between Latvian media enterprises and foreign investors, and the same in building industry. Areas with the greatest number of acquisition transactions are displayed in Table 2.

Conclusion is that capital is being invested in enterprises with considerable added value and prospective cash flow. 
Table 2: Acquisition operations of Latvian enterprises in industry perspective (buyers are foreign investors)

\begin{tabular}{|l|l|l|l|}
\hline Industry & 2008 & 2007 & 2006 \\
\hline Motor-car Industry & 1 & 0 & 1 \\
\hline Gambling & 2 & 0 & 1 \\
\hline Office Furniture, Manufacturing and Selling & 4 & 1 & 0 \\
\hline Construction & 3 & 0 & 0 \\
\hline Building Material Selling & 1 & 0 & 0 \\
\hline Other & 4 & 5 & 1 \\
\hline Finances and Insurance & 1 & 7 & 3 \\
\hline IT, Communication & 1 & 2 & 2 \\
\hline Wood, Metal Processing, Building Material & 1 & 2 & 3 \\
\hline Media & 3 & 0 & 1 \\
\hline $\begin{array}{l}\text { Food, Catering Industry, Alcohol Production and } \\
\text { Selling }\end{array}$ & 8 & 2 & 3 \\
\hline Tourism, Air Transport & 2 & 1 & 2 \\
\hline Room Maintenance & 0 & 1 & 1 \\
\hline Total: & 31 & 21 & 18 \\
\hline
\end{tabular}

Latvian enterprises which changed their owners to foreign investors in 2008 are reflected in Table 3. There is tight information available about the transactions in the public space. Purchasing of Inc. "Lode" lately has been one of the most notable public- to- private acquisitions, as the enterprise has been removed from stock market and is being administrated as company of private capital. Purchasing price for $82,8 \%$ shares attains 23,9 million euro, furthermore former shareholders received twice as the price of stock exchange.

Another significant event in 2008 was inability to close one of the most pricy deals in Latvian economics, i.e. privatization of state telecommunication enterprise Lattelecom. Approximate value of the deal was calculated within 380-440 millions euro, and one of the world's major investment companies Blackstone Group was attracted as potential buyer. The deal was expected to be arranged as MBO or management buyout, which means that the shareholders buy out the company and are supported by financial investors. The deal was not closed and now is put off indefinitely, without explaining the obstacles to society.

Table 3: Most notable acquiring deals in Latvia in 2008

\begin{tabular}{|c|c|c|c|c|}
\hline $\begin{array}{l}\text { Purchased } \\
\text { enterprise }\end{array}$ & Industry & Buyer & Country & $\begin{array}{l}\text { Type } \\
\text { Investor }\end{array}$ \\
\hline Latcharter & $\begin{array}{l}\text { Air } \\
\text { Transport }\end{array}$ & Icelandair & Iceland & $\begin{array}{l}\text { Strategic } \\
\text { Investor }\end{array}$ \\
\hline L.I.O.N. \& Ko & $\begin{array}{l}\text { Alcohol } \\
\text { Selling }\end{array}$ & Liviko & Estonia & $\begin{array}{l}\text { Strategic } \\
\text { Investor }\end{array}$ \\
\hline FFL & $\begin{array}{l}\text { Food } \\
\text { Wholesale }\end{array}$ & $\begin{array}{l}\text { Premia Tallinn } \\
\text { Cold Store }\end{array}$ & Estonia & $\begin{array}{l}\text { Strategic } \\
\text { Investor }\end{array}$ \\
\hline
\end{tabular}




\begin{tabular}{|l|l|l|l|l|} 
Kolonna & Trade & Douglas & Great Britain & $\begin{array}{l}\text { Strategic } \\
\text { Investor }\end{array}$ \\
\hline $\begin{array}{l}\text { BM Auto/ Baltic } \\
\text { Motors }\end{array}$ & $\begin{array}{l}\text { Motor-car } \\
\text { Industry }\end{array}$ & Inchape Group & Great Britain & $\begin{array}{l}\text { Strategic } \\
\text { Investor }\end{array}$ \\
\hline $\begin{array}{l}\text { Vika Wood/ Vika } \\
\text { Timber }\end{array}$ & $\begin{array}{l}\text { Wood- } \\
\text { processing }\end{array}$ & $\begin{array}{l}\text { Norvik finanšu } \\
\text { holdings }\end{array}$ & Iceland & $\begin{array}{l}\text { Financial } \\
\text { Investor }\end{array}$ \\
\hline LEC & Building & Alta Capital & Estonia & $\begin{array}{l}\text { Financial } \\
\text { Investor }\end{array}$ \\
\hline $\begin{array}{l}\text { Kalnozols } \\
\text { Celtniecība }\end{array}$ & Building & MG Baltic & Lithuania & $\begin{array}{l}\text { Financial } \\
\text { Investor }\end{array}$ \\
\hline & Building & $\begin{array}{l}\text { Capital } \\
\text { International } \\
\text { inc }\end{array}$ & Cyprus & $\begin{array}{l}\text { Financial } \\
\text { Investor }\end{array}$ \\
\hline
\end{tabular}

Activity of Latvian investors purchasing enterprises in domestic market is insignificant. In 2008 one of the leading telecommunication companies Baltcom Ltd. expanded by obtaining seven small internet providers, and in 2007 the major local transaction has been merger between building companies Aile and Tapex. Industries with common local merger deals are following: pharmacy, gas retail, dairy industry. In these operations it is basically acquisition of particular products, not the whole company with its concept.

Several local venture capital funds are founded in Latvia, e.g. Zaḷās Gaismas Investīciju Fonds, Eko Investors. The core specialty of the enterprises is to promote use of venture capital in entrepreneurial environment, and they are supported by institutions of European Union, however some leveraged buyout has been performed by local funds. It has to be admitted that venture capital investment funds in Latvia are in their early stage of development, for example comparing to Estonia where venture funds are expanding and purchasing enterprises in neighbor countries.

If the economic situation in the country gets worse, we can forecast even larger invasion of foreign investors in Latvia because the local investors will have even less opportunities to finance deals from their own funds and attracting them from local financial institutions.

\section{Conclusions}

In the light of all stated above utilizing borrowed capital for financing acquisitions of enterprises has the following advantages:

○ "Debt discipline". Due to liabilities assumed by company, it stimulates management to focus on arranging economic activities, which might have been canceled or delayed. ${ }^{9}$

- Enterprise can boost its value by increasing the burden of liabilities up to level with the highest profitability of equity. 
- Equity often includes managers together with investors, thus inspiring (or even requiring) higher management to invest a remarkable amount of their personal funds in to the transaction.

The analysis of M\&A in Latvia shows the following tendencies in acquisition and selling market in Latvia:

- The enterprise acquisition market in Latvia is developing successfully in spite of the economic recession that is reflected in the negative GDP growth and the budget deficit.

- If the economic situation in the country gets worse, we can forecast even larger invasion of foreign investors in Latvia.

- Crises attract investors because then you can buy enterprises at a good price. Still many financial investors wait because they hope that it will be possible to buy an enterprise at a still lower price than at present.

- Now we have a buyers' market because there is uncertainty about the near future, the shareholders have fewer illusions about the value of the enterprise and they tend to think more about selling the enterprise than a year ago.

- During recession buyers in the area of enterprise mergers and acquisitions have a new challenge because of the more complicated and more expensive availability of the resources. Therefore we can forecast that the deals will be for smaller sums, but their number will be larger.

- Up to now the enterprises have not been forced to consolidate in order to optimize costs and to make production more efficient. Therefore in the further periods probably we can anticipate consolidation processes in the Baltic States.

\section{References}

European Central Bank., 2007. Large Banks and Private Equity -sponsored leveraged Buyouts in The EU European Central

Bank16http://www.ecb.int/pub/pdf/other/largebanksandprivateequity200704en.pdf [ Accessed 15.03.2009]

Tuck School of Business at Dartmouth., 2003. Note on Leverage Buyouts [Tuck School of Business at Dartmouth p.6.,http://mba.tuck.dartmouth.edu/pecenter/research/pdfs/LBO_Note.pdf [Accessed 12.02.2009]

Chaudhry, A.,2008. Trends in M\&A activity - an increasingly hostile environment TooStep. http://toostep.com/trends/recent_trends_in_ma_activity_--_increasingly_hostile_e [Accessed 23.02.2009]

Blaydon, C., Wainwright, F.,2006. The Balance between debt and added value London: Financial Times, http://www.ft.com/cms/s/2/9b8481ba-4e32-11db-bcbc0000779e2340.html [Accessed 12.02.2009] 
Vanaga, A. Investori Latviju nesmādē.In: Dienas Bizness, Nr. 20, 30.01. 2009, p.15. Dieziña, S. Investorus interesē lielie.In: Dienas Bizness, Nr. 67 ,08.03. 2009,p. 8.

Rulle, B. Valdība uz miljonu darījuma sliekšņa . Rīga: Diena, 2008 [Accessed 12.02.2009] http://jauna.diena.lv/lat/politics/printed/valdiiba_uz_miljonu_dariijuma_sliekshnja 2008.gadā Latvijā visvairāk investējuši Ziemel̦valstu un igauņu uzṇēmēji . Rīga: Frut, 2008 [Accessed 23.08.2009]. http://news.frut.lv/lv/economics/43511.

Global Economic Outlook. Fitchratings.com [ Accessed 15.03.2009]

http://www.fitchratings.com/jsp/corporate/LoginController.faces?script_name=\%2F corporate\%2Freports\%2Freport_frame.cfm\%3Frpt_id\%3D412506. 
